Laskowska, A. (2017). The Green bond as a prospective instrument of the global debt market. Copernican Journal of Finance \& Accounting, 6(4), 69-83. http://dx.doi.org/10.12775/CJFA.2017.023

\author{
ANNA LASKOWSKA* \\ Nicolaus Copernicus University in Toruń
}

\title{
THE GREEN BOND AS A PROSPECTIVE INSTRUMENT OF THE GLOBAL DEBT MARKET
}

Keywords: green bond, ecological financial market, global debt market.

J E L Classification: G11, Q54, Q56.

\begin{abstract}
Green debt is viewed as one of the youngest segments on the global financial market. Green bonds were defined as fixed-income securities, issued in order to obtain the capital for further financing or refinancing of undertakings contributing to the improvement of natural environment. In other words, to develop economy which is low-carbon and resistant to climate changes. They are relatively recent instruments, which have quickly become a substantial part of the dynamic ecological trend on the financial market. The research objective of the article is to identify the factors determining the development of the green bonds market. It is reasonable to systematize the stimuli of the evolution of this process, as the green bonds potential has not been fully utilized yet. Research methods applied were: critical analysis of the subject literature as well as reports on green bonds, data analysis from international ecological financial market, inductive method and the author's own didactical material containing the case studies of five selected issuances of green bonds. The studies on subject literature were supplemented by an in-depth observation of how dynamically the green bonds market was developing in years 2012-2017. The outcome of the research: basic determinants of ecological bonds refer to demand, supply as well as realities and predictions regarding the functioning of the market. The research process confirmed that green bonds constitute a prospective dimension of the global debt market. It should be underlined, however,
\end{abstract}

Date of submission: March 5, 2018; date of acceptance: April 10, 2018.

* Contact information: anna.las@doktorant.umk.pl, Nicolaus Copernicus University in Toruń, Gagarina 13a, 87-100 Toruń, Poland, phone: +48 5661146 34; ORCID ID: http://orcid.org/0000-0002-4103-4755. 
that if the environmental bonds segment is to develop rapidly, it is necessary to remove any barriers hindering its advancement, including low ecological awareness among the society or, in some cases, the country's passivity towards pro-environmental policies.

\section{IIINTRODUCTION}

Globally monitored consequences of ecosystem balance being disrupted, including climate changes, require undertaking decisive actions aimed at improvement of the condition of the natural environment. Due to the indubitable impact economic activity has on nature, the issue also becomes more economyrelated, what is expressed by the very popular concepts of corporate social responsibility, socially responsible investment and greening finance (Ryszawska, 2016 , p. 187). It has to be stated that counteracting the degradation of environment requires unprecedented cooperation across borders. The partnership joint actions entail certain capital input. Therefore, participation of the capital segment in the activities is reasonable - it can mobilize large financial resources from the entire globe to support ecological initiatives through so called ecological instruments of the capital market. The aim of the hereby thesis is one of those instruments, namely the green bond.

Green bonds are debt instruments financing environmental investments. Although the idea of using securities to accomplish environmental undertakings appeared in the financial world long time ago, labelled green bonds are relatively young. However, it should be highlighted that they have quickly become a substantial part of the dynamic ecological trend on the capital market.

The aim of the article is to identify the factors determining development of the green bonds market. It is reasonable to systematize the stimuli of the evolution of this process, as the green bonds potential has not been fully utilized yet. The green debt market analysis is to present the green bond as a prospective instrument of the global debt market.

\section{THE RESEARCH METHODOLOGY AND THE COURSE OF THE RESEARCH PROCES}

The hereby paper contains descriptive scientific research and the methods used during the preparation of the thesis were as follows: critical analysis of the subject literature as well as reports on green bonds, data analysis from 
international ecological financial market, inductive method and the author's own didactical material containing the case studies of five selected issuances of green bonds. The studies on subject literature were supplemented by an in-depth observation of how dynamically the green bonds market was developing in years 2012-2017. The research process allowed to systematise the knowledge concerning the relatively new, but rapidly growing segment of the capital market.

\section{THE ESSENCE OF GREEN BONDS}

Green bonds were defined as fixed-income securities, issued in order to obtain the capital for further financing or refinancing of undertakings contributing to the improvement of natural environment. In other words, to develop economy which is low-carbon and resistant to climate changes. This definition also includes "climate bonds". Moreover, green bonds are also presented in literature as "environmental bonds" (Kaminker \& Steward, 2012, p. 34).

After the analysis of how green bonds function it can be stated that they are standard bonds with just one reservation - the funds obtained must be used for pro-ecological purposes. Apart from supporting the environment, the essential objective of green bonds is stable income, thus they do not differ much from their classical equivalent (Laskowska, 2017, p. 5). Nonetheless, environmental investments are subject to financial risk connected with the uncertainty of anticipated effects and difficulties in raising capital. In this connection, green bonds are often offered in secured or guaranteed form, also as hybrid and revenue bonds (Marszałek \& Daszyńska-Żygadło, 2016, p. 947).

The main fields in the development of which green bonds play an active role are renewable energy, energy efficiency, clean transportation, water and waste management. The undertakings financing environmental bonds are still worth taking a closer look at. For example Climate Bonds Initiative (CBI) - an organization which investigates the segment of those instruments - presents broad sector-based guidelines for potential green bond issuers, forming a classification of subjects for investment named the green bond taxonomy. Examplary investment qualification criteria for the purpose of the notion of ecologically responsible bonds are presented in the diagram below. 
Scheme 1. Green bonds taxonomy

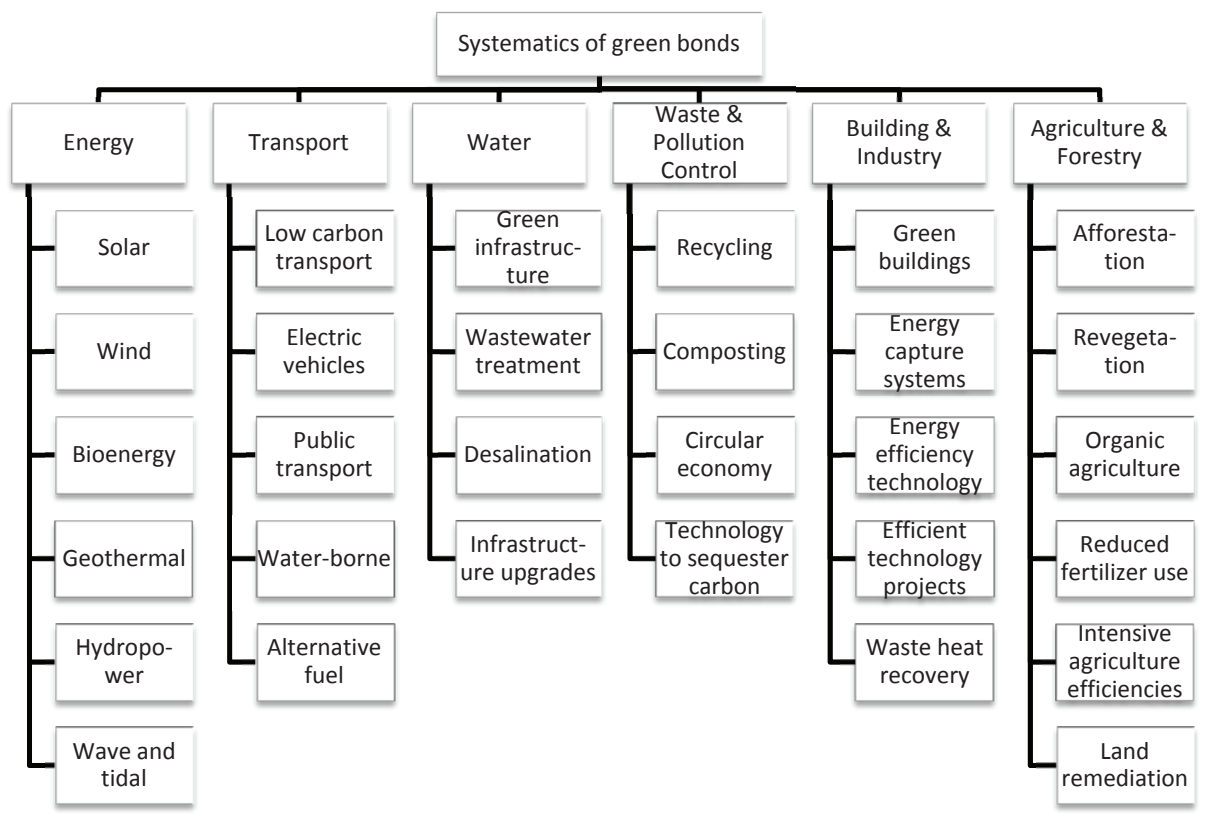

S o u r c e : the author's elaboration based on: www1.

\section{STRONG INTERNATIONAL GREEN BONDS ALLIES}

It should be noted that the green bonds market can be discussed owing to two international institutions of the financial sector, contributing to the balanced growth of regions. They are European Investment Bank (EIB) and the World Bank.

First widely recognized green bonds were issued in 2007 and 2008 ${ }^{1}$. In 2007 the European Union began the realisation of its strategy regarding climate changes. EIB was searching for an idea to challenge capital market participants

1 Nevertheless, it should be added that the beginnings of present-day green bonds appeared before year 2000. One of the first bonds issuers carrying the environmental character (to an extent) were specialist public German banks Deutsche Ausgleichsbank and Kreditanstal fuer Wiederaufbau, as well as Austrian Oesterreichische Kommunalkredit AG bank. In their policy, contemporarily functioning green bonds prioritise assumptions of economy being low-carbon and resistant to climate changes. The premises were not present before year 2007 (Dziawgo, 1997, pp. 120, 133). 
to finance "green" projects. Green bonds became the solution to the problem. In 2007 EIB issued the world's first environmental bonds, under the name of Climate Awareness Bonds. The example was quickly followed by the World Bank, which issued its first green debt instruments a year after - in 2008. The activity of EIB and the World Bank as green issuers is growing each year (Trompeter, 2017, pp. 4-5).

In terms of the effects of pro-environmental activities of the above mentioned financial institutions, EIB issued over 19 billion green eurobonds in 11 currencies, enabling the financing of 146 undertakings referring to renewable energy sources and energy efficiency in 44 countries (European Investment Bank, 2017). In 2008 the World Bank issued 132 environmental bonds in 18 currencies. As a result, the Green Bond Programme reached 10.1 billion USD for the financing of 91 projects concerning low-carbon economy and adopting to climate changes in 28 countries (World Bank, 2017, p. 6).

It has been 10 years since first green bonds were issued - on that day EIB and the World Bank stated that fighting against climate changes requires global cooperation across borders and decided to address the green debt, rightfully foreseeing long-term development perspectives. The volume of green bonds is growing and the World Bank, together with EIB are viewed as their pioneers. It should also be added that, despite diminishing share of green bonds issuance from development banks in the overall green debt, the World Bank and EIB are still planning to be international environmental bonds allies. On December $12^{\text {th }}, 2017$, during "One Planet Summit", the two entities obliged themselves to increase their capital flows, profiled to switch for green economy. That was proved by the fact that International Finance Corporation (a member of the World Bank Group) commenced their works on a new fund, Amundi - Green Cornerstone Bond Fund, with 2 billion USD of value. The aim of Green Cornerstone Bond Fund is developing local capital markets and financing for environmental purposes through green bonds (Climate Bonds Initiative, 2018, p. 3).

\section{THE INFLUENCE OF GREEN BONDS ON THE WIDENING OF THE RANGE OF CAPITAL MARKET INSTRUMENTS}

One of the key premises for the development of the green bonds market is constant work on the construction of the instruments. Perfecting has become one of indispensable aims of any activity, including investing. Referring to the slogan: there is no success without development, new, interesting types of green 
bonds can be observed on the capital market, which is making attempts to increase its attractiveness.

It should be noted that, by virtue of the kind of the issuer and the structure, seven kinds of green bonds can be distinguished (OECD \& Bloomberg Philanthropies, 2015, p. 12):

- corporate bond,

- project bond,

- asset-backed security,

- municipal bond,

- sovereign bond,

- supranational bond,

- financial sector bond.

The above list will most probably expand as works on the constructions of environmental bonds are still in progress. Until recently on the market there have been no sovereign green bonds. It is worth highlighting in this place that on December $12^{\text {th }}, 2016$ Poland was the first to issue bonds as the government, becoming the pioneer in this field. The interest in green issuance was so big (mainly from German and Austrian investors) that it resulted in an increase of the debt securities quota to 750 million euro from the initially adopted level of 500 million euro. Governmental authorities in Poland managed to use the green debt potential anticipating the rest of the world. For example France, which issued green bonds on January 24th, 2017 (Laskowska, 2017, pp. 5-6). Next issues of sovereign green bonds in 2017 were conducted by such countries as Fiji and Nigeria (Bloomberg, 2017; International Finance Corporation, 2017). Moreover, sovereign green bonds can leave a lasting mark in the ecological strategies of countries, what can be exemplified by Poland which made the second issuance of green debt valued at 1 billion euro in the beginning of 2018 (Financial Times, 2018).

Making references to the interesting constructions of green bonds it is worth to mention about unconventional instruments, namely green sukuk. It constitutes a good blend of the positive features of green bonds and attractive features of Islamic finances, basing on based on the rules of Shari'ah (Alam, Duygun \& Turk-Ariss, 2016, p. 167). Another issue that should be addressed is the influence of green bonds on the capital market development. As a matter of fact, the segment has a substantial impact on the widening of other financial instruments range. Stock exchange markets very often create lists of green bonds. The summary indicates fulfilling ecological criteria but does not follow the fi- 
nancial results. Therefore certain stock market indices of environmental bonds were implemented, i.a. Solactive Green Bond Index Series (the world's first index of the kind), S\&P Green Bond Index and ChinaBond China Climate-Aligned Bond Index. Apart from acting as a market benchmak, those indices constitute a basis for financial products, i.e. ETF (e.g. Lyxor Green Bond UCITS ETF) or structured products. Such market infrastructure promotes investments and liquidity on the market of environmental debt securities (Climate Bonds Initiative, 2017a, pp. 4-5).

\section{ECOHUMANISM AS A TREND DETERMINING THE DEVELOPMENT OF THE GREEN BONDS MARKET}

Due to the policy of more efficient management of resources, sustainable development is a basis for green bonds. Therefore, the idea of ecohumanism is becoming more popular and it is understood as a partnership cooperation for the purpose of development and common good: society, natural environment and future generations (Michnowski, 2008, p. 108).

The interest in green assets among bondholders and issuers is growing, as well as the awareness among investor nowadays, regarding the threats caused by unbridled economic expansion. The investors can also connect facts that exploiting limited natural resources diminishes the chance to fulfil the needs of future generations, what creates various responsibilities and obligations - also ecological (Werther \& Chandler, 2006, p. 6).

It is worth noting that sometimes a stimuli for introducing the idea of ecohumanism is not only environmental protection but viability (financial and image-related) of such policy. Taking into account material reasons, very often those branches green bonds base on, i.e. renewable energy, clean technologies, electrical transportation or organic farming, are viewed as more prospective and therefore profitable.

On the other hand, a part of the market participants is interested in environmental bonds only because the issue of ecology is becoming more popular and fashionable. It is worth being a part of the trend, using the marketing advantages of environmental etiquette to improve one's image. The purpose of the involvement in the green capital market is to present the entity (an investor or issuer) in a better light. It should be underlined, however, that not everyone is convinced by the "green" image of the financial market. The issue of determi- 
nants of creating ecological financial instruments, including green bonds, is and will still be controversial for the general public (Szpringer, 2009, pp. 113-115).

The question of veracity of motives for creating green bonds is connected with the bondholders' uncertainty as to the use of the funds invested and the impact they have on the improvement of the natural environment. The issue, which may become a barrier for the development of green bonds, turned out to be a determinant of the works on the instrument credibility.

Basing on the Post Issuance Reporting in the Green Bond Market report it should be noted that nearly $80 \%$ of issuers disclosed to the public the reports on the use of proceeds from bondholders. The highest reporting rate was among government agencies, state-bank entities and commercial banks. Over $85 \%$ of bonds under contain the information about the category or level of the project. Studies also indicate that $39 \%$ of green bonds actually are audited. The results presented prove the "greenness" of the idea of green bonds undergoes continuous verification by both regulating bodies and issuers (Climate Bonds Initiative, 2017b, pp. 2-8).

As it can be seen, the responsibility of issuers bases not only on the promises made before, and during the issue, but also on the monitoring of the financed projects. What is more, when reporting, the issuers have a unique opportunity to establish relationships with bondholders, as well as potential investors and other participants of the segment, thus confirming their ecological credibility. In this connection it can be expected, that green bonds reports will become more comprehensive (Climate Bonds Initiative, 2017b, p. 3).

\section{THE DYNAMICS OF GREEN BONDS DEVELOPMENT AND HIGH EXPECTATIONS} IN REGARD TO THE FUTURE

The next argument in favour of green bonds is the dynamics of their development. Size and structure of the green bonds market are regularly estimated and updated by CBI. The bonds issuance status is consequently presented in reports published since 2012, which contribute to the protection of climate. The volume of green bonds issue, number of issuers and green debt value in years 2012-2017 was subject to analysis in table 1. 
Table 1. The green bonds market development in years $2012-2017^{2}$

\begin{tabular}{|c|c|c|c|}
\hline \hline Year & $\begin{array}{c}\text { The volume } \\
\text { of green bonds }\end{array}$ & $\begin{array}{c}\text { The number } \\
\text { of green issuers }\end{array}$ & $\begin{array}{c}\text { The value of the bonds } \\
\text { market (bn USD) }\end{array}$ \\
\hline 2012 & over 1,000 & 207 & 174 \\
\hline 2013 & 1,200 & 260 & 346 \\
\hline 2014 & 2,369 & 248 & 502.6 \\
\hline 2015 & 2,769 & 407 & 597.7 \\
\hline 2016 & 3,590 & 780 & 694 \\
\hline 2017 & 3,493 & 1,128 & 895 \\
\hline \hline
\end{tabular}

S o u r c e : the author's elaboration based on: www2.

Analysing the table above it should be stated that the issuance rate of labelled green bonds generally increases each year and development of the green bonds segment is noticeable. The only exception appeared in 2017, when a slight decrease of observed instruments was noticed. When examining the volume of green bonds in each unit of time, compared to the previous period, it should be underlined that year 2014 is characterised by the highest chain index of dynamics (197 per cent). That constitutes an increase of 1,169 bonds when compared to year 2013.

What should not be overlooked either is the growing interest among issuers in this asset class. In 2012 the number was slightly exceeding 200 and just within five years it increased five times, reaching 1,128 issuers of green debt. The dynamics each year is relatively unstable. The pace of changes varies from 5 to 92 per cent. It should be underlined, however, that almost each year there was an increase in the number of environmental issuers, except for 2014.

The last issuance under analysis basing on the table above is the value of green bonds located in the financial market. The greatest absolute change took place in 2017 - a 201 billion USD increase. The value of global green bonds market was estimated in the Bonds and Climate Change State of the Market 2017 report at 895 billion USD. For that reason 2017 is referred to as the year of the world's record-breaking environmental bonds supply. China Railway significantly contributed to the result, issuing green bonds worth 222 billion USD.

2 All green bonds issued between January 1st, 2005 and June 30th, 2017 were included in the data set. 
The issuance mentioned covered the costs of improvement and development of 22,000 kilometres of high-speed railway system and was the largest issue in entire year 2017 (Climate Bonds Initiative, 2017c, p. 6).

What can convince to issue and purchase green bonds is the segment's dynamics of development presented above. It foresees further expansion of green debt. In relation to the fact, that year 2017 was very favourable for the green bonds market in terms of the supply and a breakthrough year regarding sovereign green bonds, the expectations towards the segment are growing. The CBI analytics anticipate that in 2020 the issuance will surpass the value of 1 trillion USD (Climate Bonds Initiative, 2017c, p. 24). Those great expectations are shared by the heads of capital debts from the world's 20 best investment banks and their thoughts concerning the debt in 2018 were described in the GlobalCapital market study. The banks' representatives look most favourably on the increase in the value of the bonds market with the involvement of financial institutions, states and emerging markets. Moreover, out of the debt instruments mentioned, the debt specialists are most optimistic about the green bonds development (scheme 2) (GlobalCapital, 2018, p. 15).

Scheme 2. Answers to the question:

"Which products are you most optimistic about by volume?"

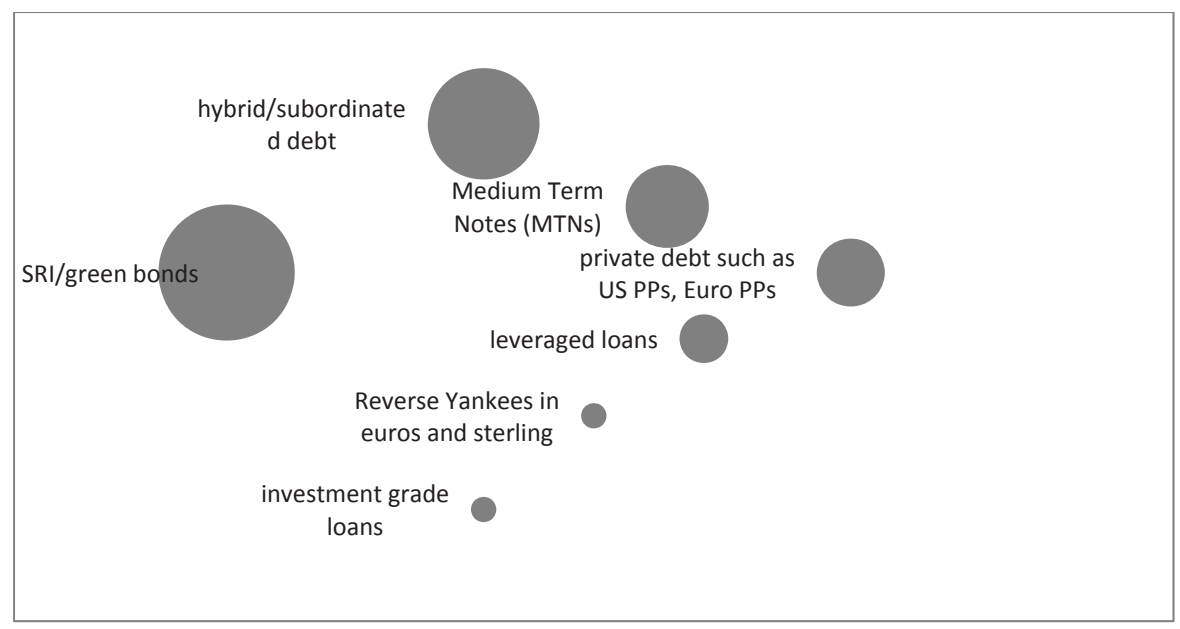

S o u r c e : the author's elaboration based on: GlobalCapital, 2018, p. 15. 
Further positive conclusions are brought by the answer to the last question of the GlobalCapital report: "How strongly do you agree with the following statements?". Out of eight statements, the heads of debts fully agree with one: "Divestment from fossil fuels will become a growing trend" (GlobalCapital, 2018, p. 17). Fossil fuels divestment implies limitation or withdrawal of capital (for example through bonds disposal) from institutions making money from fossil fuels mining and combustion. The move uses a number of tools to put pressure, facilitate resigning from fossil fuel supplies among institutional investors and encourage them to invest in renewable energy sources. Divestment from fossil fuels has been gaining the global significance in recent years (Healy \& Debski, 2017, p. 5). Taking into account the GlobalCapital report, the process will become a more popular trend. It is a good sign for the widening of green bonds range, as the above written strategy complies with the bonds policy.

\section{GREEN BONDS CASE STUDIES}

Green bonds are a tool aimed at protecting and shaping the natural environment. The case studies below present five selected environmental bonds with respect to formal details of issue as well as previously defined conditions for development of the green debt segment. The issuances were selected for comparison basing on the issuer date criterion, namely they had to be issued within the last six months.

Table 2. Case studies of selected green bonds

\begin{tabular}{|c|c|c|c|c|c|}
\hline Issuer name & $\begin{array}{c}\text { European } \\
\text { Investment Bank }\end{array}$ & $\begin{array}{l}\text { Federal Govern- } \\
\text { ment of Nigeria }\end{array}$ & $\begin{array}{l}\text { Province } \\
\text { of Ontario }\end{array}$ & Iberdrola & Westpac \\
\hline Country of issue & International & Nigeria & Canada & Spain & Australia \\
\hline Issue date & March 16, 2018 & $\begin{array}{l}\text { December 20, } \\
2017\end{array}$ & February 5, 2018 & March 26, 2018 & $\begin{array}{l}\text { February 28, } \\
2018\end{array}$ \\
\hline Maturity date & $\begin{array}{l}\text { November 15, } \\
2047\end{array}$ & $\begin{array}{l}\text { December 22, } \\
2022\end{array}$ & February 5, 2025 & March 26, 2024 & $\begin{array}{l}\text { February 28, } \\
2023\end{array}$ \\
\hline Tenor (in years) & 29 & 5 & 7 & 6 & 5 \\
\hline Currency & EUR & NGN & CAD & EUR & AUD \\
\hline Issue value (m) & 250 & 10,700 & 1,000 & 700 & 117 \\
\hline $\begin{array}{l}\text { Dollar issue } \\
\text { value }(\mathrm{m})\end{array}$ & 309.177 & 30 & 801 & 861 & 91 \\
\hline
\end{tabular}


Table 2. Case studies of selected green bonds

\begin{tabular}{|l|l|l|l|l|l|}
\hline \hline \multicolumn{1}{|c|}{ Issuer name } & \multicolumn{1}{|c|}{$\begin{array}{c}\text { European } \\
\text { Investment Bank }\end{array}$} & $\begin{array}{l}\text { Federal Govern- } \\
\text { ment of Nigeria }\end{array}$ & $\begin{array}{c}\text { Province } \\
\text { of Ontario }\end{array}$ & \multicolumn{1}{|c|}{ Iberdrola } & Westpac \\
\hline \hline $\begin{array}{l}\text { Kind of green } \\
\text { bonds }\end{array}$ & $\begin{array}{l}\text { supranational } \\
\text { bond }\end{array}$ & sovereign bond & municipal bond & corporate bond & $\begin{array}{l}\text { financial sector } \\
\text { bond }\end{array}$ \\
\hline Use of proceeds & $\begin{array}{l}\text { hydropower, } \\
\text { solar, wind and } \\
\text { geothermal ener- } \\
\text { gy, waste heat } \\
\text { recovery, green } \\
\text { building }\end{array}$ & $\begin{array}{l}\text { solar energy, } \\
\text { energy efficiency } \\
\text { technology, or- } \\
\text { ganic agriculture } \\
\text { afforestation }\end{array}$ & $\begin{array}{l}\text { low carbon and } \\
\text { public transport, } \\
\text { electric vehicles, } \\
\text { efficient techno- } \\
\text { logy projects }\end{array}$ & $\begin{array}{l}\text { solar and wind } \\
\text { energy, energy } \\
\text { efficient techno- } \\
\text { logy projects }\end{array}$ & $\begin{array}{l}\text { solar and wind } \\
\text { energy, low car- } \\
\text { bon transport, } \\
\text { electric vehicles, } \\
\text { efficient, green } \\
\text { buildings }\end{array}$ \\
\hline $\begin{array}{l}\text { Ecohumanism in } \\
\text { practise }\end{array}$ & $\begin{array}{l}\text { Green Bond } \\
\text { Principles }\end{array}$ & $\begin{array}{l}\text { Green Bond } \\
\text { Guidelines }\end{array}$ & $\begin{array}{l}\text { Ontario Green } \\
\text { Bond Framework }\end{array}$ & $\begin{array}{l}\text { Iberdola Frame- } \\
\text { work for Green } \\
\text { Financing }\end{array}$ & $\begin{array}{l}\text { Westpac's } \\
\text { Climate Bond } \\
\text { Framework }\end{array}$ \\
\hline $\begin{array}{l}\text { Ecological verifi- } \\
\text { cation of issues } \\
\text { / audit }\end{array}$ & KPMG & DNV GL & not certificated & not certificated & EY Asia Pacific \\
\hline $\begin{array}{l}\text { The role of } \\
\text { international } \\
\text { development } \\
\text { banks }\end{array}$ & issuer & $\begin{array}{l}\text { the World Bank } \\
\text { supports the } \\
\text { issue }\end{array}$ & inspiration & inspiration & inspiration \\
\hline \hline
\end{tabular}

S o u r c e : the author's elaboration based on: www3, www4.

As it was mentioned before, one of the key requirements for the green bonds development is constant work on the structure of the instruments, what results in various types of green bonds. Table 2 allows to present the factor, as it show five different environmental bonds by the issuer type. Moreover, the issues are listed in different currencies and they even come from different continents, showing the global reach of the discussed instruments.

The growing pressure put by the more aware investors, business partners, politicians, media and non-governmental organizations, the staff's viewpoint and the will to improve the image are factors that can encourage institutions to implement the idea of ecohumanism through the issue of green bonds (Dziawgo, 2010, p. 27). The first practical step to achieve it is elaborating and introducing transparent procedures the issuer follows before, during and after the green issue. Moreover, the rules also help in removing the significant barrier hindering the green bonds development, namely the lack of credibility of the instruments. The best solution to confirm the authenticity of issue is reporting and ecological verification, for example by the institutions mentioned in table 2. Unfortunately, auditing has not become a widely utilized method yet. 
What should also be reminded is the role international development banks play in the development of green bonds market. Their contribution to the segments as issuers and decision-makers rendered the green bonds available of investors from all over the world. Various issuers benefit from the investment banks' support, thus creating traditional or untypical bonds structures, for example the Federal Government of Nigeria. For other issuers the activity of international development banks within the green debt sector is inspiring.

What cannot be confirmed via the analysis of the analysis of table 2 is the previously defined advantage of green bonds - its development dynamics, as the case studies only presents selected, individual issuances. However, the development of green bonds market was presented and analysed in table 1.

\section{ConCLUSIONS}

The green debt is one of the most recent segments on the global financial market. Notwithstanding, on the basis of the analysis of green bonds issuance, several development trends of the segment under research can be observed.

The basic determinants of green bonds development refer to the supply (issuers), demand (investors, bondholders) and also the realities and anticipations regarding functioning of the market. The following stimulants can be distinguished: extensive involvement of international development banks as issuers, constant expansion of the range of instruments into new types, increase in the liquidity the capital market due to instruments basing their construction on green bonds, potential of ecologically responsible investors, continuous work on the credibility of the green bond label and also hitherto remarkable development dynamics. Furthermore, another premise for the green debt evolution is the positive outlook of specialists, regarding the future of the segment. Based on the mentioned factors it can be stated, that green bonds constitute a prospective dimension of the global debt market.

It has to be noted, though, that in order for the environmental bonds segment to continue developing dynamically, the following barriers to the expansion are necessary to be removed: low ecological awareness or, in some cases, the country's passivity towards pro-environmental policies. Ecological education is a solution to those. As to the country's ecological strategy, the impulse encouraging institutions to act more actively in the field of the environmental protection is the pressure from others and legislation. Especially the European Commission favours the projects which follow the principles of sustainable 
development, ecology and social responsibility. It was expressed in numerous reports, for example the Opinion of European Economic and Social Committee on Socially responsible financial products or Europe 2020. On these grounds it may be concluded, that low-carbon economy is becoming the priority and further expansion of green bonds and other ecological financial instruments is plausible in the future.

\section{REFERENCES}

Alam, N., Duygun, M., \& Turk-Ariss, R. (2016). Green Sukuk: An Innovation in Islamic Capital Market. In A. Dorsman, Ö. Arslan-Ayaydinm, M. Baha Karan (Eds.). Energy and Finance: Sustainability in the Energy Industry. Heidelberg: Springer.

Bloomberg (2017). Oil Giant Nigeria to Sell First African Sovereign Green Bond, http:// www.bloomberg.com/news/articles/2017-12-14/top-oil-producer-pioneers-african-sovereign-green-bonds (accessed: 17.02.2018).

Climate Bonds Initiative (2017a). The Role of Exchanges in Accelerating the Growth of the Green Bond Market, http://www.climatebonds.net/resources/reports/role-exchanges-accelerating-growth-green-bond-market (accessed: 15.02.2018).

Climate Bonds Initiative (2017b). Post Issuance Reporting in the Green Bond Market, http://www.climatebonds.net/files/files/UoP_FINAL_120717.pdf (accessed: 18.02.2018).

Climate Bonds Initiative (2017c). Bonds and Climate Change: State of the Market 2017, http://www.climatebonds.net/files/reports/cbi-sotm_2017-bondsclimatechange. pdf (accessed: 19.02.2018).

Climate Bonds Initiative (2018). Green Bond Highlights 2017, http://www.climatebonds. net/files/reports/cbi-green-bonds-highlights-2017.pdf (accessed: 15.02.2018).

Dziawgo, L. (1997). Papiery wartościowe w ochronie środowiska. (Securities in Environmental Protection.) Toruń: TNOiK Dom Organizatora.

Dziawgo, L. (2010). Zielony rynek finansowy. Ekologiczna ewolucja rynku finansowego. (Green Financial Market. Financial Market Ecological Evolution.) Warszawa: PWE.

European Investment Bank (2017). 10th Anniversary of "Green Bonds" Celebrated in Luxembourg, http://www.eib.org/infocentre/press/releases/all/2017/2017-184-10emeanniversaire-des-emissions-vertes-celebre-au-luxembourg.htm (accessed: 15.02.2018).

Financial Times (2018). Poland's Second Green Bond Is a First for Markets, http://www. ft.com/content/27aa83ae-0684-11e8-9650-9c0ad2d7c5b5 (accessed: 15.02.2018).

GlobalCapital (2018). Review 2017 Outlook 2018, http://globalcapital.euromoneycdn. com/Media/documents/euroweek/pdfs/2018/GlobalCapital\%20ROTY\%202017. pdf (accessed: 19.02.2018).

Healy, N., \& Debski, J. (2016). Fossil Fuel Divestment: Implications for the Future of Sustainability Discourse and Action within Higher Education. Local Environment: The International Journal of Justice and Sustainability, 22(6), 699-724. http://dx.doi.org/ 10.1080/13549839.2016.1256382. 
International Finance Corporation (2017). A Green Bond to Help Fiji Secure a Greener Future, http://www.ifc.org/wps/wcm/connect/news_ext_content/ifc_external_ corporate_site/news+and+events/news/cm-stories/fiji-green-bond-for-a-greenerfuture (accessed: 17.02.2018).

Kaminker, C., \& Steward, F. (2012). The Role of Institutional Investors in Financing Clean Energy. OECD Working Papers on Finance. Insurance and Private Pensions. No. 23. OECD Publishing. http://dx.doi.org/10.1787/5k9312v2116f-en.

Laskowska, A. (2017). Polska światowym prekursorem zielonych obligacji skarbowych. (Poland as the Global Precursor of Sovereign Green Bonds.) Profit Journal, 2(18), 5-6.

Marszałek, J., \& Daszyńska-Żygadło, K. (2016). Charakterystyka globalnego rynku obligacji klimatycznych. (The Climate Bond Global Market Characteristics.) Finanse, Rynki Finansowe, Ubezpieczenia, (Finance, Financial Markets, Insurance.) 4(82), 945-955. http://dx.doi.org/10.18276/frfu.2016.4.82/1-78.

Michnowski, L. (2008). Ecohumanism as a Developmental Crossing. In S. Sharma, P.K. Sharma (Eds.). Transformative Pathways: Attainable Utopias. Jaipur: Prateeksha Publications.

OECD, \& Bloomberg Philanthropies (2015). Green Bonds: Mobilising the Debt Capital Markets for a Low-Carbon Transition: Policy Perspectives, http://www.oecd.org/ environment/cc/Green\%20bonds\%20PP\%20\%5Bf3\%5D\%20\%5Blr\%5D.pdf (accessed: 17.02 .2018 ).

Ryszawska, B. (2016). Sustainability Transition Needs Sustainable Finance. Copernican Journal of Finance \& Accounting, 5(1), 185-194. http://dx.doi.org/10.12775/ CJFA.2016.011.

Szpringer, W. (2009). Społeczna odpowiedzialność banków. Między ochrona konsumenta a osłonq socjalnq. (Social Responsibility of Banks. Between Consumer Protection and Cover Social.) Warszawa: Wolters Kluwer.

Trompeter, L. (2017). Green Is Good: How Green Bonds Cultivated into Wall Street's Environmental Paradox. Sustainable Development Law \& Policy, 17(2), 3-11; 40-43.

Werther, W.B., \& Chandler, D. (2006). Strategic Corporate Social Responsibility: Stakeholders in a Global Environment. Thousand Oaks: SAGE Publications.

World Bank (2017). Green Bond Impact Report 2017, http://treasury.worldbank.org/ cmd/pdf/WorldBankGreenBondImpactReport.pdf (accessed: 15.02.2018).

(www1) Climate Bonds Initative - Taxonomy, http://www.climatebonds.net/standards/taxonomy (accessed: 15.02.2018).

(www2) Climate Bonds Initative - Market, http://www.climatebonds.net/market (accessed: 19.02.2018).

(www3) Climate Bonds Initative - Certification, http://www.climatebonds.net/standards/certification (accessed: 7.04.2018).

(www4) The Green Bond Base, http://www.greenbonddata.org (accessed: 7.04.2018). 